\title{
Physical-chemical analysis of the cerebrospinal fluid of healthy dogs submitted to different storage periods and temperatures
}

\author{
Análise físico-química do líquido cerebroespinal de cães hígidos em diferentes períodos e temperaturas de \\ estocagem
}

Paula Nunes Rosato ${ }^{1}$ Fernanda Gomes Velasque Gama ${ }^{1}$ Aureo Evangelista Santana ${ }^{2}$

\begin{abstract}
Disorders involving the nervous system have a great importance in veterinary medicine because they have a high incidence and few auxiliary tools for their diagnostic, prognostic and evaluation of the employed therapy. Today, the diagnostic is based, mainly, on the patient history and neurologic examination. Hence, evaluation of the cerebrospinal fluid elements is one of the few alternatives to clinically access the central nervous system (CNS). Even with the great usefullness of the physical-chemical and cytoscopy exams of the CSF in veterinary neurology, there are few studies concerning the stability of its elements under freezing storage. The present study was aimed at verifing the influence of temperature and period of conservation on physical-chemical characteristics of the CSF of healthy dogs. For that purpose, CSF samples were collected by puncture of the cisterna magna of dogs clinically healthy, and then were analysed for density, $\mathrm{pH}$, glucorrhachia, total proteins and activity of the enzymes creatine kinase $(C K)$ and aspartate aminotransferase (AST), after storage in different temperatures $\left(25^{\circ} \mathrm{C}, 4^{\circ} \mathrm{C}\right.$ and $\left.-4^{\circ} \mathrm{C}\right)$ and periods (immediately after collection and after 24 hours, 48 hours, a week and a month). Regarding the obtained results it was possible to verify that the parameters studied were stable up to a month of storage, under freezing at $-4^{\circ} \mathrm{C}$.
\end{abstract}

Key words: cerebrospinal fluid, dogs, storage, temperature.

\section{RESUMO}

Disfunções envolvendo o sistema nervoso são de grande importância na Medicina Veterinária, pois tratam-se de enfermidades de elevada incidência e com poucos subsídios auxiliares no seu diagnóstico, prognóstico e na avaliação de terapias empregadas. Ainda hoje, o diagnóstico baseia-se, em grande parte, no histórico e no exame clínico neurológico. Dessa forma, a análise dos constituintes do fluido cefalorraquidiano torna-se uma das poucas alternativas de acesso clínico ao sistema nervoso central (SNC). Mesmo com a grande utilidade do exame físico-químico e citoscópico do liquor na neurologia veterinária, poucos são os estudos sobre a estabilidade dos seus constituintes sob estocagem. Dessa forma, o presente trabalho teve como finalidade verificar a influência da temperatura e do tempo de conservação nas características físico-químicas do liquor de cães hígidos. Para tanto, foram coletadas amostras de LCR, através da punção da cisterna cerebelo-medular de cães clinicamente sadios, as quais foram submetidas à análise da densidade específica, do $\mathrm{pH}$, da glicorraquia, das proteínas totais e das atividades das enzimas creatina quinase $(C K)$ e aspartato aminotransferase (AST), após conservá-las em diferentes temperaturas $\left(25^{\circ} \mathrm{C}\right.$, $4^{\circ} \mathrm{C}$ e $-4^{\circ} \mathrm{C}$ ) e por diferentes períodos de tempo (logo após a colheita, 24 horas, 48 horas, uma semana e um mês). Dentre os resultados obtidos, foi possível verificar, principalmente, que houve estabilidade dos parâmetros estudados por até um mês de estocagem nas amostras mantidas sob a temperaturas de congelamento de $-4^{\circ} \mathrm{C}$.

Palavras-chave: liquor, cães, estocagem, temperatura.

\section{INTRODUCTION}

Cerebrospinal fluid (CSF) is produced mainly in the cerebral ventricles and bathes the central nervous system (CNS) and part of the peripheric system. Its functions are to protect, imbibe, maintain and, also, promote the defense of the nervous system against injury agents. The preservation of these properties and functions is only possible due to the active exchange that occurs continually and that promotes the dynamism of the elements presented in the cerebrospinal fluid. Thus, these elements can reflect normal and pathological conditions, once they vary,

'Faculdade de Ciências Agrárias e Veterinária (FCAV), Universidade Estadual Paulista (UNESP), Campus de Jaboticabal, SP, Brasil. ${ }^{2}$ Departamento de Clínica e Cirurgia Veterinária, FCAV, Unesp, Campus de Jaboticabal, Via de Acesso Prof. Paulo Donato Castellane s/n, Zona Rural, 14884-900, Jaboticabal, SP, Brasil. E-mail: santana@fcav.unesp.br. Autor para correspondência. 
particularly in pathologic situations. So, the collection and analysis of CSF have been demonstrated to be a suitable and on effective way to access and to evaluate the nervous system, regarding the diagnosis and prognosis of several disorders.

WRIGHT (1978) has suggested that it is possible to apply to CSF some of the several tests used for blood and other biological fluids, obtaining important information with highly diagnostic value, emphasizing the color, aspect, $\mathrm{pH}$, specific gravity, glucose, total proteins and type of cells presented in CSF. CHRISMAN (1985); TIPOLD (2003) have reported that the normal CSF is clear and colourless, but in pathologic conditions can be yellow or xanthochromic, indicating the presence of bilirubine, deriving from an old hemorrhage; and it can also vary from rosy to reddish which may indicate an accidental hemorrhage at the moment of collection.

Regarding the aspect, the normal cerebrospinal fluid is fully transparent. WRIGHT (1978), BRAUND (1994); FELDMAND (1997) and FREEMAN \& RASKIN (2003) have reported that turbidity in CSF is associated, mainly, to an increase of cells, but only with counts greater than 500 cells $\mu \mathrm{L}^{-1}$. According to TIPOLD (2003), a high protein content can enhance this turbidity and produce a more viscous fluid. FEITOSA et al. (1997) have found turbidity in CSF samples from dogs with canine distemper and they have related this finding to the increase of total protein.

The normal specific gravity for CSF ranges from 1.003 to 1.012 , according to KAY et al. (1974). MAYHEW \& BEAL (1980) have affirmed that elevated values may occur in cases of pleocytosis and increased protein levels, which was also reported by FEITOSA et al. (1997). FELDMAN (1997) has reported that in experimental studies with animals, it was verified homeostatic mechanisms that maintain a relatively constant $\mathrm{pH}$, similar to that from blood, even when changes occur in the systemic $\mathrm{pH}$.

According to COLES (1986); COATES (2000), the normal CSF, derived from the cisterna magna, has about 12 to $40 \mathrm{mg} \mathrm{dL}^{-1}$ of protein, while FERNANDES (1990) has found mean values around $20 \mathrm{mg} \mathrm{dL}^{-1}$ and BRAUND (1994) normal values ranging from 25 to $30 \mathrm{mg} \mathrm{dL}^{-1}$, these authors have reported that CSF protein is almost entirely constituted of albumin, but small amounts of globulins may also be found. However, when the nervous system is affected, the protein levels may be increased, particularly in cases of encephalitis, as reported by SORJONEM (1987) and TUDURY et al. (1997) in dogs with canine distemper, toxoplasmosis, meningitis, spinal cord or brain abscessation, and also in non-inflammatory conditions characterized by convulsion and uremia.
Glucose is another chemical component to be quantified in the CSF and its concentration depends on the blood glucose level and the rate of metabolism in the central nervous system, TIPOLD (2003). MCGUIRK \&MACWILLIAMS (1992); FELDMAN (1997); FREEMAN \& RASKIN (2003) have suggested that glucorrhachia varies directly with the glycemia and the glucose concentration of CSF is 60 to $80 \%$ of plasma in normal dogs, ranging from 40 to $80 \mathrm{mg} \mathrm{dL}^{-1}$. COLES (1986) has reported that in infectious encephalitis, specially bacterial, it is possible to observe hypoglycorrhachia due to the comsumption of glucose by microorganisms.

Investigation of the activity of some enzymes presented in the CSF have been usefull on the stablishment of a diagnostic and prognostic of any disease that occurs in the central nervous system. So, elevation in the activities of enzymes such as creatine kinase (CK), lactic dehydrogenase (LDH) and aspartate aminotransferase (AST) have been considered indicators of lesions in the nervous tissue, as reported by CHRISMAN (1985); COOK \& DENICOLA (1988); FELDMAN (1997). According to THRALL (2004), these enzymes are big protein molecules, which do not cross the blood-brain barrier. Thus, elevated activities of these enzymes in the CSF may indicate injury and necrosis of the central nervous tissue, and elevations in their catalytic activities, in these conditions, do not occur simultaneously in blood serum. Studies in felines accomplished by MAAS (1977) have shown that acute injuries in the central nervous system coincide with higher activity of these enzymes, and this activity is proportional to the severity of the lesions in the tissue. According to INDRIERI et al. (1980) and FELDMAN (1997) the prognostic is considered unfavourable when elevated activities of CK and AST are found in the CSF.

Physical-chemical and cytoscopic exams are very usefull in the practice of veterinary neurology, but few are the studied related to stability of CSF elements under storage. Thus, the present study is aimed at verifying the influence of storage periods and temperatures on the CSF of dogs, regarding specific gravity, $\mathrm{pH}$, glucose, total protein, and activity of the enzymes: creatine kinase and aspartate aminotransferase.

\section{MATERIAL AND METHODS}

Thirty mongrel dogs, males and females, weighing over $10 \mathrm{~kg}$, distributed into individual kennels, with water and food ad libitum, were used. Dogs were submitted to a rigorous clinical examination, followed 
by routine haematology, biochemistry, coproparasitologic, urinary analysis and sorological tests for canine distemper and toxoplasmosis.

The cerebrospinal fluid was obtained from animals under general anesthesia with $\operatorname{Propofol}^{\mathrm{b}}(5.0 \mathrm{mg}$ $\left.\mathrm{kg}^{-1}\right)$, after sedation with Levomepromazine ${ }^{\mathrm{a}}\left(1.0 \mathrm{mg} \mathrm{kg}^{-1}\right)$. The samples were collected from the cisterna magna using a $25 \times 8$ needle and then, transfered into 5 aliquots in glass recipients. A maximum of $1 \mathrm{ml}$ for every $5 \mathrm{~kg}$ was collected from each animal, as mentioned by COLES (1986), in order to avoid any damage to the integrity of the intracranial pressure and cerebral structures.

Animals were allocated into 3 groups of 10 (ten): $\mathrm{G} 1, \mathrm{G} 2$ and $\mathrm{G} 3$ according to the storage temperature of $25^{\circ} \mathrm{C}, 4^{\circ} \mathrm{C}$ and $-4^{\circ} \mathrm{C}$, respectively. The collected samples were distributed into 5 aliquots containing a minimum of $400 \mu \mathrm{l}$, and were evaluated at the following periods: immediately after collection (M0), 24 hours (M1), 48 hours (M2), a week (M3) and a month (M4) later. Each group was evaluated in the different periods for $\mathrm{pH}$, specific gravity, glucose, total protein and activity of the CSF enzymes: creatine kinase and aspartate aminotransferase.

Specific gravity was obtained by using the refractometer ${ }^{\mathrm{c}}$ and $\mathrm{pH}$ was determined by using $\mathrm{pH}$ reagent strips ${ }^{\mathrm{d}}$. Glucose quantitation was determined through the use of $\mathrm{HK}$ reagent $\mathrm{kit}^{\mathrm{e}}$, with aid of a biochemical analyser ${ }^{\mathrm{f}}$, and colorimetric lecture. Total protein quantitation was conducted by using the Sensi Prot $^{\mathrm{e}}$ reagent kit, through the method of red pirogalol (BEHR et al., 2003), and the lectures were performed in the biochemical analyserf .

Enzyme activities (creatine kinase, lactic dehydrogenase and aspartate aminotransferase) were determined by the reagent kit ${ }^{\mathrm{e}}$ (kinetic method) and the lectures were made in a biochemical analyserf .

\section{RESULTS AND DISCUSSION}

The values for $\mathrm{pH}$ were very stable during the entire experiment, with mean value of $8.0 \pm 0.0$, in all groups (G1, G2 and G3) and periods (M0 to M4). This result enables to notice the stability of $\mathrm{pH}$ of the cerebrospinal fluid, which was not verified by SCHENCK et al. (1995), who have evidenced alteration in this parameter in serum samples of dogs stored at $20^{\circ} \mathrm{C}$ and $4^{\circ} \mathrm{C}$ for 9 hours, and at $-10^{\circ} \mathrm{C}$ in periods equal or over three days. For specific gravity, it was noticed that the values were statiscally similar during the whole storage period in all evaluated temperatures (Table 1).

Regarding the values obtained for glucose concentration in the CSF, it was verified that in the samples stored at $25^{\circ} \mathrm{C}$ there was a significant statistical decrease starting from 48 hours of storage at $4^{\circ} \mathrm{C}$, until a month, while at $-4^{\circ} \mathrm{C}$ no statistical difference was observed even after a month of storage (Table 2). These findings are in accordance with those from THORESEN et al. (1995), who noticed glucose stability in serum samples of dogs under freezing storage. Protein concentration in CSF did not show significant statistical alterations during the entire experiment (Table 2). THORESEN et al. (1992); THORESEN et al. (1995) have shown that this parameter was stable in serum samples of dogs stored either at room temperature $\left(20^{\circ} \mathrm{C}\right)$ or under freezing $\left(-20^{\circ} \mathrm{C}\right.$ and $\left.-70^{\circ} \mathrm{C}\right)$. Although the values obtained for total protein have not been considered statistically different, it was observed a remarkable oscillation in the means of the different groups and experimental periods, which indicates an important variability, mostly concerning the low protein concentration in the CSF and the clinical significance of subtle alterations in this parameter.

The values obtained for creatine kinase were stable at $25^{\circ} \mathrm{C}$ for 48 hours and at the other temperatures during the whole experimental period (Table 3 ). These

Table 1 - Mean values and standard deviation obtained for cerebrospinal fluid specific gravity in dogs from groups G1 $\left(25^{\circ} \mathrm{C}\right), \mathrm{G} 2\left(4^{\circ} \mathrm{C}\right)$ and G3 $\left(-4^{\circ} \mathrm{C}\right)$, in the storage periods M0 (after collection), M1 (24h), M2 (48h), M3 (one week) and M4 (one month). Jaboticabal (SP), 2004.

\begin{tabular}{lccccc}
\hline \multicolumn{5}{c}{ Specific gravity } \\
\hline & \multicolumn{5}{c}{ Periods } \\
\cline { 2 - 6 } Groups & M0 & M1 & M2 & M3 & M4 \\
\hline G1 & $1,005 \pm 0.001 \mathrm{ab}$ & $1,006 \pm 0.001 \mathrm{ab}$ & $1,006 \pm 0.000 \mathrm{a}$ & $1,005 \pm 0.000 \mathrm{~b}$ & $1,005 \pm 0.000 \mathrm{ab}$ \\
G2 & $1,005 \pm 0.000 \mathrm{a}$ & $1,005 \pm 0.000 \mathrm{a}$ & $1,005 \pm 0.000 \mathrm{a}$ & $1,005 \pm 0.000 \mathrm{a}$ & $1,005 \pm 0.000 \mathrm{a}$ \\
G3 & $1,005 \pm 0.003 \mathrm{a}$ & $1,006 \pm 0.001 \mathrm{a}$ & $1,006 \pm 0.001 \mathrm{a}$ & $1,005 \pm 0.001 \mathrm{a}$ & $1,005 \pm 0.000 \mathrm{a}$ \\
CV & 23.8 & & & & \\
\hline
\end{tabular}

Means followed by the same small letter, do not differ when using the Tukey test $(\mathrm{P}>0.05)$.

Ciência Rural, v.36, n.6, nov-dez, 2006. 
Table 2 - Mean values and standard deviation obtained for cerebrospinal fluid glucose $\left(\mathrm{mg} \mathrm{dL}^{-1}\right)$ and total proteins $\left(\mathrm{mg} \mathrm{dL}^{-1}\right)$ in dogs from groups G1 $\left(25^{\circ} \mathrm{C}\right), \mathrm{G} 2\left(4^{\circ} \mathrm{C}\right)$ and $\mathrm{G} 3\left(-4^{\circ} \mathrm{C}\right)$, in the storage periods M0 (after collection), M1 (24h), M2 (48h), M3 (one week) and M4 (one month). Jaboticabal (SP), 2004

\begin{tabular}{|c|c|c|c|c|c|c|}
\hline & \multirow[b]{2}{*}{ Groups } & \multicolumn{5}{|c|}{ Periods } \\
\hline & & M0 & M1 & M2 & M3 & M4 \\
\hline \multirow{4}{*}{$\begin{array}{l}\text { Glicose } \\
\left(\mathrm{mg} \mathrm{dL}^{-1}\right)\end{array}$} & G1 & $98.2 \pm 23.2 \mathrm{a}$ & $89.1 \pm 23.1 \mathrm{ab}$ & $97.5 \pm 18.4 \mathrm{a}$ & $52.8 \pm 40.8 b$ & $9.8 \pm 21.5 \mathrm{c}$ \\
\hline & G2 & $127.6 \pm 29.5 a$ & $108.7 \pm 18.6 \mathrm{a}$ & $114.1 \pm 18.5 \mathrm{a}$ & $125.3 \pm 45.0 \mathrm{a}$ & $28.9 \pm 42.9 b$ \\
\hline & G3 & $108.3 \pm 48.2 \mathrm{a}$ & $104.2 \pm 37.2 \mathrm{a}$ & $103.9 \pm 42.3 \mathrm{a}$ & $98.6 \pm 41.0 \mathrm{a}$ & $101.9 \pm 35.3 \mathrm{a}$ \\
\hline & $\mathrm{CV}$ & 23.8 & & & & \\
\hline \multirow{4}{*}{$\begin{array}{l}\text { Total proteins } \\
\left(\mathrm{mg} \mathrm{dL}^{-1}\right)\end{array}$} & G1 & $28.5 \pm 8.7 \mathrm{a}$ & $19.8 \pm 8.1 \mathrm{a}$ & $21.1 \pm 5.9 \mathrm{a}$ & $28.3 \pm 11.9 a$ & $23.4 \pm 21.2 \mathrm{a}$ \\
\hline & G2 & $26.4 \pm 10.9 a$ & $27.4 \pm 9.6 \mathrm{a}$ & $24.8 \pm 13.6 \mathrm{a}$ & $21.1 \pm 8.6 \mathrm{a}$ & $25.8 \pm 7.8 \mathrm{a}$ \\
\hline & G3 & $33.0 \pm 15.3 \mathrm{a}$ & $38.5 \pm 11.9 \mathrm{a}$ & $32.0 \pm 14.0 \mathrm{a}$ & $29.3 \pm 11.7 a$ & $32.4 \pm 11.5 \mathrm{a}$ \\
\hline & $\mathrm{CV}$ & 36.4 & & & & \\
\hline
\end{tabular}

Means followed by the same small letter, do not differ when using the Tukey test $(\mathrm{P}>0.05)$.

values were somehow in accordance with those from KANEKO et al. (1997), once these authors have noticed stability of $\mathrm{CK}$ at $25^{\circ} \mathrm{C}$ for 48 hours, although at $4^{\circ} \mathrm{C}$ for only a week. Data obtained from the enzyme aspartate aminotransferase did not present significant statistical difference in the different groups and periods of experimentation (Table 3), demonstrating to be a stable parameter, as reported by THORESEN et al. (1992); THORESEN et al. (1995), in serum and plasma samples of dogs, at room temperature $\left(20^{\circ} \mathrm{C}\right)$ and under freezing $\left(-20^{\circ} \mathrm{C}\right.$ and $\left.-70^{\circ} \mathrm{C}\right)$, respectively.

\section{CONCLUSION}

The results in the present study allow us to conclude that the CSF samples stored at room temperature, the glucorrhachia and the activity of the enzyme creatine kinase were stable up to 48 hours while specific gravity, $\mathrm{pH}$ and the activity of the enzyme aspartate aminotransferase up to a month of storage. Regarding the temperature $4^{\circ} \mathrm{C}$, glucose concentration was diminushed after a month of storage while specific gravity, $\mathrm{pH}$, creatine kinase and aspartate aminotransferase were stable during the whole experimental period. Under freezing at $-4^{\circ} \mathrm{C}$, all parameters were stable during the entire experimental period.

\section{SOURCES AND MANUFACTURES}

a Neozine - Aventis Pharma LTDA - Santo Amaro - São Paulo - Brasil

Table 3 - Mean values and standard deviation obtained for cerebrospinal fluid creatine kinase activity $\left(\mathrm{U} \mathrm{L}^{-1}\right)$ and aspartate aminotransferase activity $\left(\mathrm{U} \mathrm{L}^{-1}\right)$ in dogs from groups $\mathrm{G} 1\left(25^{\circ} \mathrm{C}\right), \mathrm{G} 2\left(4^{\circ} \mathrm{C}\right)$ and $\mathrm{G} 3\left(-4^{\circ} \mathrm{C}\right)$, in the storage periods M0 (after collection), M1 $(24 \mathrm{~h}), \mathrm{M} 2$ (48h), M3 (one week) and M4 (one month). Jaboticabal (SP), 2004.

\begin{tabular}{|c|c|c|c|c|c|c|}
\hline & \multirow[b]{2}{*}{ Groups } & \multicolumn{5}{|c|}{ Periods } \\
\hline & & M0 & M1 & M2 & M3 & M4 \\
\hline \multirow{4}{*}{$\begin{array}{l}\mathrm{CK} \\
\left(\mathrm{U} \mathrm{L}^{-1}\right)\end{array}$} & G1 & $53.0 \pm 50.1 \mathrm{a}$ & $45.7 \pm 39.9 \mathrm{ab}$ & $40.9 \pm 30.3 \mathrm{ab}$ & $28.8 \pm 10.1 b c$ & $16.8 \pm 16.9 \mathrm{c}$ \\
\hline & $\mathrm{G} 2$ & $31.2 \pm 11.6 \mathrm{a}$ & $33.6 \pm 12.4 \mathrm{a}$ & $31.2 \pm 11.6 \mathrm{a}$ & $33.6 \pm 12.4 \mathrm{a}$ & $24.0 \pm 16.0 \mathrm{a}$ \\
\hline & G3 & $33.6 \pm 16.2 \mathrm{ab}$ & $36.1 \pm 26.2 \mathrm{ab}$ & $43.3 \pm 25.0 \mathrm{a}$ & $33.6 \pm 12.4 \mathrm{ab}$ & $19.2 \pm 10.1 \mathrm{~b}$ \\
\hline & $\mathrm{CV}$ & 39.5 & & & & \\
\hline \multirow{4}{*}{$\begin{array}{l}\text { Total proteins } \\
\left(\mathrm{U} \mathrm{L}^{-1}\right)\end{array}$} & G1 & $18.7 \pm 6.1 \mathrm{a}$ & $18.2 \pm 5.2 \mathrm{a}$ & $18.2 \pm 5.5 \mathrm{a}$ & $15.5 \pm 7.9 \mathrm{a}$ & $11.2 \pm 10.8 \mathrm{a}$ \\
\hline & G2 & $15.6 \pm 5.2 \mathrm{ab}$ & $18.8 \pm 6.7 \mathrm{ab}$ & $19.8 \pm 7.7 \mathrm{ab}$ & $15.1 \pm 5.5 b$ & $24.1 \pm 11.1 \mathrm{a}$ \\
\hline & G3 & $20.2 \pm 5.1 \mathrm{a}$ & $17.5 \pm 3.5 \mathrm{a}$ & $18.6 \pm 5.5 a$ & $18.2 \pm 5.2 \mathrm{a}$ & $16.0 \pm 2.1 \mathrm{a}$ \\
\hline & $\mathrm{CV}$ & 30.77 & & & & \\
\hline
\end{tabular}

Means followed by the same small letter, do not differ when using the Tukey test $(\mathrm{P}>0.05)$.

Ciência Rural, v.36, n.6, nov-dez, 2006. 
b Propofol - Fresenius Kabi LTDA - Campinas - São Paulo Brasil

c Atago Co LTD - Tokyo - Japão

${ }^{\mathrm{d}}$ Merck do Brasil - Rio de Janeiro - Brasil

e Labtest Diagnóstica - Lagoa Santa - Minas gerais - Brasil

${ }^{\mathrm{f}}$ Labquest - Lagoa Santa - Minas gerais - Brasil

\section{ACKNOWLEDGEMENT}

The authors thanks Fundação de Amparo a Pesquisa do Estado de São Paulo for the financial support.

\section{REFERENCES}

BEHR, S. et al. Assessment of pyrogallol red technique for total protein measurement in the cerebrospinal fluid of dogs. Journal of Small Animal Practice, v.44, n.12, p.530-533, 2003.

BRAUND, K.G. Diagnostic techniques. In: BRAUND, K.G. Clinical syndromes in veterinary neurology. St Louis: Mosby, 1994. p.333-421.

CHRISMAN, C.L. Investigações auxiliares especiais. In: CHRISMAN, C.L. Neurologia dos pequenos animais. São Paulo: Roca, 1985. p.63-96.

COATES. J.R. Cerebrospinal proteins. In: FELDMAN, B.F. et al. Shalm's veterinary hematology. Philadelphia: Lippincot, 2000. p.917-927.

COLES, E.H. Cerebrospinal fluid. In: COLES, E.H. Veterinary clinical pathology. Philadelphia: Saunder, 1986. p.267-278.

COOK, J.R.; DENICOLA, D.B. Cerebrospinal fluid. Veterinary Clinics of North America: Small Animal Pratice, v.18, n.3, p.475-497, 1988.

FEITOSA, M.M. et al. Avaliação física, citológica, conteúdo de proteínas e determinação qualitativa de globulinas do liquor de cães com encefalite por cinomose. Brazilian Journal Of Veterinary Reseach Of Animal Science, v.34, n.03, p.147151, 1997.

FELDMAN, B.F. Cerebrospinal fluid. In: KANEKO, J.J. Clinical Biochemistry Of Domestic Animals. 5.ed. San Diego: Academic, 1997. p.786-822.

FERNANDES, R.W. Determinação dos valores liquóricos normais de glicose, proteína, globulina, uréia, creatina fosfoquinase (CK), aspartato aminotransferase (AST), leucócitos e da coloração, turbidez e coagubilidade em cães sadios. Brazilian Journal of Veterinary Research Animal Science, v.27, n.02, p.209-216, 1990.

FREEMAN, K.P.; RASKIN, R.E. Citologia do sistema nervosa central . In: RASKIN, R.E.; MEYER, D.J. Atlas De Citologia De Cães E Gatos. São Paulo: Roca, 2003. p.275-308.

INDRIERI, R.J. et al. Critical evaluation of creatine phosphokinase in cerebrospinal fluid of dogs with neurologic disease. American Journal Of Veterinary Research, v.41, n.08, p.1299-1303, 1980.

KANECO, J.J. et al. Clinical Biochemistry Of Domestic Animals. 5.ed. San Diego: Academic, 1997. p.888.

KAY, W.J. et al. Cerebrospinal fluid. Veterinary Clinics Of North America, v.04, n.02, p.419-35, 1974.

MAAS, I.R.A. Cerebrospinal fluid enzymes in acute brain injury. Journal of Neurology, Neurosurgery and Psychiatry, v.44, p.666-674, 1977.

MAYHEW, I.G.; BEAL, C.R. Techniques of analysis of cerebrospinal fluid. Veterinary Clinics of North America: Small Animal Pratice, v.10, n.1, p.155-177, 1980.

MCGUIRK, S.M.; MACWILLIAMS, P.S. Cerebrospinal fluid. In: COWELl, R.L.; TYler, R.D. Cytology And Hematology Of The Horse. California: American veterinary publications, 1992. p.163-171.

SCHENCK, P. A. et al. Effects of storage on serum ionised calcium and $\mathrm{pH}$ values in clinically normal dogs. American Journal of Veterinary Research, v.56, n.03, p.304-307, 1995.

SORJONEM, D.C. Total protein, albumin quota, and electrophoretic patterns in cerebrospinal fluid of dogs with central nervous system disorders. American Journal of Veterinary Reseach, v.48, n.2, p.301-305, 1987.

THRALL, M.A. et al. Laboratory detection of muscle injury. In: THRALL, M.A. et al. Veterinary Hematology And Clinical Chemistry. Philadelphia: Lippincot, 2004. p.417-420.

THORESEN, S.I. et al. Efects of storage time chemistry results from canine whole blood, heparinized whole blood, serum and heparinized plasma. Veterinary Clinical Pathology, v.21, n.3, p.88-94, 1992.

THORESEN, S.I. et al. Efects of storage and freezing temperature on clinical chemical parameters from canine serum and heparinized plasma. Veterinary Clinical Pathology, v.24, n.4, p.129-133, 1995.

TIPOLD, A. Cerebrospinal fluid. In: VITE, C.H.; BRAUND, K.G. Braund's Clinical Neurology In Small Animals: Localization, Diagnosis And Treatment, 2003. Capturado em 15 jan. 2006. On line. Disponível na internet: http:// www.ivis.org/advances/Vite/toc.asp.

TUDURY, E.A. et al. Observações clínicas e laboratoriais em cães com cinomose nervosa. Ciência rural, v.27, n.2, p.229235, 1997.

WRIGHT, J.A. Evaluation of cerebrospinal fluid in the dog. Veterinary Record, v.103, p.48-51, 1978. 